\title{
Determinant Analysis of Low Birth Weight among Young Pregnant Women in Blitar District
}

\author{
Etti Suryani, Yuly Peristiowati, \\ Yenny Puspitasari \\ Health Science Institute of Strada \\ Indonesia \\ Email: \\ ettisuryani@gmail.com
}

Received : October 5, 2020

Accepted : November 28, 2020

Published : November 30, 2020

\begin{abstract}
Background: Low birth weight, commonly called LBW, is a major cause of infant mortality in Indonesia whereas its prevalence tends to increase from year to year. This study aimed to analyze the determinants of gravida status, routine antenatal care, and comorbidities in LBW among young pregnant women in Blitar. The research design was case-control using proportional cluster random sampling with a sample of 223 respondents. The data were analyzed with the binary logistic regression. The results showed 214 respondents $(96 \%)$ were primigravida, 23 respondents $(10.3 \%)$ were not attended antenatal care routinely, 66 respondents (30\%) had comorbidity, and 20 respondents (9\%) delivered LBW baby. The statistical analysis of logistic regression showed there was no influence from gravida status and comorbidities, and routine antenatal care indicateda p-value of 0.000 which meant it was determined LBW among $<20$ years old pregnant women in Blitar. The interpretation of odd value was the group of $<20$ years old pregnant women who were not attended routine ANC had a risk of 10 times to deliver LBW baby compared to the group of $<20$ years old pregnant women who attended routine ANC. This study concluded that routine antennal care might prevent LBW for young pregnant women
\end{abstract}

Keywords: Comorbidity, low birth weight, gravida status, routine antenatal care

Copyright (C) 2020 IIK STRADA Indonesia All right reserved.

This is an open-acces article distributed under the terms of the Creative Commons Attribution-ShareAlike 4.0 International License.

\section{BACKGROUND}

Low Birth Weight(LBW)is the main factor of infant mortality in Indonesia according to the data of basic health study in 2018. The prevalence of low birth weight in infantsat 0-9 monthsold was $6.2 \%$ and the prevalence tends to increase from year to year (Ministry of Health of Republic of Indonesia, 2018b). Low birth weight in East Java in 2019 was the main cause of infant mortality by $32.61 \%$ which was higher from another cause, asphyxia by $21.43 \%$ (Ministry of Health of Republic of Indonesia, 2018a). In Blitar, there were 590 cases of low birth weight from the total of 15,341 live births in 2019 and the infant mortality due to low birth weight was 34 infants which were higher than in 2018 namely 583 cases from 15,427 live births (Blitar District Health Office, 2020).

Low birth weight is defined as weight at birth less than 2500 grams regardless of gestational age (Kosim, 2012). Increased LBW cases are likely because of many high-risk pregnant women including too young, too old, too many children, and too close the interval between a child and 
another. Besides, maternal diseases contributed to LBW such as HIV, syphilis, hepatitis B, and preeclampsia(Wati, 2013).

Antenatal Care (ANC) is also a factor of LBW particularly the routine attendance and the frequency(Rahmi, Arsyad, \& Rismayanti, 2014). Attending ANC must be done $\geq 4$ times which has a crucial contribution for the maternal women so the health staff can supervise and ensure the health of mother and child, improve and sustain the mental and physical health, detectthe complication and disability early, and plan delivery according to the due date. If the woman had less attendance in ANC, she might lack knowledge about healthy pregnancy and fetal growth and development(Rahmi et al., 2014).

Most of $<20$ years old pregnant women suffered from anemia, the basic health data recorded $84.6 \%$ anemia cases among young pregnant women in 2018 (Ministry of Health of Republic of Indonesia, 2018b). They were also suffered from chronic energy deficiencies according to the data of basic health data in 2018. There were 33.5\% of cases of chronic energy deficiencies among young pregnant women (Ministry of Health of Republic of Indonesia, 2018b).

Based on the report of Blitar District Health Office, there were 500 young pregnant women every year. In 2018, there were 528 young pregnant women while the following yearwas recorded 508 young pregnant women. This condition might affect the negative aspect of both infant mortality and life quality in the future.

\section{OBJECTIVE}

This study aimed to analyze the determinants of gravida status, routine antenatal care, and comorbidities in LBW among young pregnant women in Blitar.

\section{METHOD}

The research design in this study was a case-controldesign that analyzing the determinant of LBW among young pregnant women. The independent variables were gravida status, routine ANC, and comorbidities (anemia, chronic energy deficiency, HIV, syphilis, hepatitis B, and pre-eclampsia). The dependent variable was LBW cases in <20 years old pregnant women in Blitar District in 2019. The data collection used checklist form from on the data provided by Blitar District Health Office in 2019. The sampling technique was proportional cluster random sampling with a sample number of 223 people. The statistical analysis used binary logistic regression test. This study was approved by the ethical committee of Strada Indonesia of Health Science Institute with No. 1980/KEPK/IV/2020.

\section{RESULTS}

The results of the study showed in these tables. The tables below were presented according to the independent variables and low birth weight variable and showed the result of the statistical analysis.

Table1. The description of $<20$ years old pregnant women based on gravida status in Blitar

\begin{tabular}{lllllll}
\hline Gravida & \multicolumn{2}{l}{ Normal Birth Weight } & LBW & \multicolumn{3}{l}{ Total } \\
\cline { 2 - 7 } & $\mathrm{N}$ & $\%$ & $\mathrm{~N}$ & $\%$ & $\mathrm{~N}$ & $\%$ \\
\hline Multigravida & 9 & 100 & 0 & 0 & 9 & 100 \\
Primigravida & 194 & 90.7 & 20 & 9.3 & 214 & 100 \\
\hline
\end{tabular}

Based on table 1, many respondents here were primigravida status compared to multigravida. All pregnant women with multigravida status delivered babies with normal birth weight. The majority of respondents wereprimigravida status and delivered babies with normal birth weight (90.7\%). There were 20 babies with LBW from primigravida women (9.3\%).

Table 2.The description of $<20$ years old pregnant women based on routine antenatal care in Blitar

\begin{tabular}{lllllll}
\hline Routine ANC & \multicolumn{2}{l}{ Normal Birth Weight } & LBW & \multicolumn{3}{c}{ Total } \\
\cline { 2 - 7 } & $\mathrm{N}$ & $\%$ & $\mathrm{~N}$ & $\%$ & $\mathrm{~N}$ & $\%$ \\
\hline Yes & 189 & 94.5 & 11 & 5.5 & 200 & 100 \\
No & 14 & 60.9 & 9 & 39.1 & 23 & 100 \\
\hline
\end{tabular}

Based on table 2, many respondents attended routine ANC during maternity. The respondents attending routine ANC delivered babies with normal birth weight by $94.5 \%$ while the rest of $5.5 \%$ 
delivered babies with LBW. There were $39.1 \%$ of babies with LBW from the respondents who did not attend routine ANC and the rest of $60.9 \%$ delivered babies with normal birth weight.

Table 3.The description of $<20$ years old pregnant women based on comorbidities in Blitar District

\begin{tabular}{lllllll}
\hline Comorbidities & \multicolumn{2}{l}{ Normal Birth Weight } & LBW & \multicolumn{2}{c}{ Total } \\
\cline { 2 - 7 } & $\mathrm{N}$ & $\%$ & $\mathrm{~N}$ & $\%$ & $\mathrm{~N}$ & $\%$ \\
\hline No & 145 & 92.4 & 12 & 7.6 & 157 & 100 \\
Yes & 58 & 97.9 & 8 & 12.1 & 66 & 100 \\
\hline
\end{tabular}

Based on table 3, many respondents did not suffer any maternal disease while some of them suffered anemia, chronic energy deficiency, and pre-eclampsia. There were $92.4 \%$ young pregnant women who did not have comorbidities and delivered babies with normal birth weight while $7.6 \%$ delivered babies with LBW. In a group of young pregnant women who had comorbidities, there was 97.9\% delivered babies with normal birth weight, and $12.1 \%$ delivered babies with LBW.

Table 4.The binary regression logistic model of gravida status, routine antenatal care, and comorbidities towards low birth weight among $<20$ years old pregnant women

\begin{tabular}{llll}
\hline Variables & $\mathrm{B}$ & df & Sig. \\
\hline Gravida Status & 18,461 & 1 & 0,999 \\
Routine ANC & 2,309 & 1 & 0,000 \\
Comorbidities & 0,310 & 1 & 0,555 \\
Constant & $(-21,349)$ & 1 & 0,999 \\
\hline
\end{tabular}

The independent variables determining LBW which had p-value $<0.05$ was routine ANC. The variable of routine ANC determined LBW among <20 years old pregnant women in Blitar in 2019. The odd ratio in this model was 10.06 which interpreted $<20$ years old pregnant women who had not routine antenatal care to have 10 times greater risk to deliver low birth weight babies than pregnant women who had routine antenatal care.

\section{DISCUSSION}

Age is one of the biological characteristics contributing to increasing the risk of LBW as it is related to reproductive maturity (Mubasyiroh, Tejayanti, \& Senewe, 2016). The young woman is commonly perceived as having reproductive immaturity that can affect the maternal outcome (Mubasyiroh et al., 2016). The result of characteristics within the respondents showed the youngest age was 14 years old in Blitar. The factor of reproductive maturity in $<20$ years old combined with too young or too old factor had 2.43 greater times of risk to deliver LBW babies compared to a woman with $>2$ years of reproductive immaturity and age of 20-34 years old (Mubasyiroh et al., 2016).

The reproductive organ at $<20$ years old has not mature enough. The cervix and the uterus have not grown fully to adult size too. Those conditions might worse for adolescent pregnancy as the teenagers will be getting high risk and complications during maternity. The cases of LBW in 2010 was more occurring among $<20$ years old female due to the factor of $<2$ years reproductive maturity in those age group (Mubasyiroh et al., 2016).

Primigravida is mostly occurred among the participants in this study compared to multigravida because many respondents were less than 20 years old. The age during pregnancy is related to the marital age. Therefore, the woman having an early marital age has a big chance to get pregnant at a young age(Sholiha \& Sumarmi, 2015). In 2010, there were 46,4\% of women married before 20 years old in Indonesia (Ministry of Health of the Republic of Indonesia, 2010). The marital age has been regulated in law no. 16/2019 about the change of the law no. 1/1974 about the marriage. The national policy set the minimum of marital age for females is 19 years old, in which the previous marital age was 16 years old, considering the reproductive maturity in women.

Primigravida women at a young age were likely to get more risk of maternal and perinatal complications, such as LBW, asphyxia, premature birth, and intrauterine fetal deathcompared to primigravida women at 20-30 years old(Al-Ramahi \& Saleh, 2006). The study showed LBW babies were mostly from primigravida mother (See Table 1). The cases of LBW mostly occurred among the group of primigravida at a young age due to biological immaturity in mothers (Kovavisarach, Chairaj, 
Tosang, Asavapiriyanont, \& Chotigeat, 2010). Primigravida at a young age affected LBW cases (Prianita \& Cahyanti, 2011).

The majority of respondents tended to not check their pregnancy or attend ANC in the first trimester likely because they felt shy of their young age even ANC in the first trimester was crucial to prevent LBW. A pregnant woman who attends ANC at $>3$ monthsof gestational age was more likely to get LBW babies compared to a pregnant woman who attends ANC at $<3$ months of gestational age (Mubasyiroh et al., 2016). The first attendance (K1) for pregnant women should be done early in the first semester or before 8 weeks of gestational age (Ministry of Health of the Republic of Indonesia, 2015).

If the pregnant women did not attend ANC regularly, they will tend to get more risk having LBW babies. Routine ANC in this study was according to Ministerial Regulation No. 97 the Year 2014 namely attending ANC for once in the first and second trimester and twice in the third trimester. Mubasyiroh et al. (2016) stated that incorrect ANC attendance frequency occurred more in LBW babies than mothers attending correct ANC attendance frequency. The risk value was 1.84 greater times for pregnant women who attend ANC frequency incorrectly compared to mothers who attend ANC frequency correctly (Mubasyiroh et al., 2016).

The comorbidities in this research included anemia, chronic energy deficiency, HIV, syphilis, hepatitis B, and pre-eclampsia. Anemia in pregnancy was signed with a declined $\mathrm{Hb}$ (Hemoglobin) concentration level from the normal limit, which was $11 \mathrm{~g} / \mathrm{dL}$ in the second trimester because hemodilution or blood thinning. Anemia is related to LBW cases. A pregnant woman with chronic energy deficiency was because of unbalancing intake from energy and protein so the intake requirement in a body was insufficient. A pregnant woman with primigravida tends to suffer chronic energy deficiency while anemia is tended to be suffered among pregnant women with multigravida (Rizkah \& Mahmudiono, 2017).

The respondents in this research did not have a history of reactive results of HIV, syphilis, and hepatitis B. Some of them suffered pre-eclampsia. Pre-eclampsia risk has occurred in pregnant women who are too young ( $<20$ years old), too old ( $>34$ years old), and primigravida (Denantika, Serudji, \& Revilla, 2015). Pre-eclampsia was the risk factor to deliver LBW babies (Kurniawati, 2010). The cause why comorbidities were not a determinant of LBW was the respondents in this study did not suffer HIV, syphilis, and hepatitis B and only 1 participant suffered pre-eclampsia. Therefore, the data affected the result of statistical analysis determining the factor of LBW among young pregnant women.

In this research, $<20$ years old pregnant woman who did not attend routine ANC had a 10 times greater risk to deliver babies with LBW than pregnant women who attended routine ANC. The contribution of antenatal care is crucial to prevent the pregnancy outcome of LBW. According to the basic health data in 2010, LBW cases occurred more in pregnant women who did not attend routine ANC compared to those who attended routine ANC (Mubasyiroh et al., 2016). Routine ANC was strongly related to LBW. More routine ANC is attended by a pregnant woman, more likely the normal birth weight is to have occurred (Nurhayati, Wigunantiningsih, \& Hastutik, 2018; Putri, 2014).

The women with adolescent pregnancy were advised to check their pregnancy routinely because the primigravida women were mostly at a young age and their maternal knowledge was lacking. The maternal assessment and examination through ANC were performed by the health staffs and those have benefits for young pregnant women so they can get maternal supervision including general health conditions for mother and fetus, early detection of maternal disease and complication, and risk assessment of pregnancy. ANC consists of weight scaling, blood pressure measurement, uterine fundal height, tetanus toxoid immunization, Fe medication, the rapid test of sexually transmitted diseases, and counseling for childbirth planning and referral for the due date (Nurmalasari \& Mustofa, 2014).

LBW was caused by intrauterine growth restriction in the placenta from mother's diseases, inadequacy nutritional intake, and maternal complication that can be prevented through routine antenatal care. ANC helps pregnant women to check their fetal growth and development and improving nutritional status. A primigravida pregnant woman who did not attend routine ANC had 6.681 times greater risk to deliver a baby with LBW compared to primigravida pregnant women who attended routine ANC (Nurmalasari \& Mustofa, 2014). 
Contrasting to the study by Sholiha and Sumarmi (2015) that showed there was no relationship between ANC frequency, ANC quality, and LBW cases. Another study also stated the pregnant woman who did not attend routine ANC could deliver a baby with normal birth weight. That might happen because many pregnant women did not attend ANC for the first time in the first trimester but they often attend ANC in the second and third trimester (Putri, 2014). The risk value to deliver a baby with LBW was almost the same between the group of pregnant women who attend the first ANC in < 3 months of gestational age and the group attended the first ANC in $>3$ months of gestational age(Mubasyiroh et al., 2016).

Gravida status in the respondents was dominated by primigravida compared to multigravida, but the variable of gravida status in this study did not affect LBW cases. That was likely because mostly the age of participants was around 18-19 years old so their reproductive organs were mature even they the maternity was the primigravida. Besides, they attended routine ANC so they could improve their health status and prevent LBW cases.

The determinant from gravida status was from a pregnant woman with multigravida because they were more risk to suffer anemia 6.588 times greater than primigravida mother(Rizkah \& Mahmudiono, 2017). Meanwhile, the grand multigravida mother had a 5.789 timer greater risk of suffering anemia than primigravida mother (Rizkah \& Mahmudiono, 2017). Anemia was mentioned as a risk factor of LBW (Prawirohardjo, 2010). Anemia was affected by the frequency of pregnancy and childbirth as more frequent to get pregnant and childbirth, more likely to get iron deficiency (Manuaba, 2012).

\section{CONCLUSION}

There was no influence from gravida status and comorbidities towards LBW among young pregnant women in Blitar. This study demonstrated that routine ANC was influential factor towards LBW among young pregnant by p-value 0.000 and the odd ration in this model was predicted by 10.06 which meant the group of $<20$ years old pregnant woman who did not attend routine ANC had 10 times greater risk to deliver babies with LBW than the group of pregnant women who attended routine ANC. It was suggested for pregnant women to attend routine ANC during pregnancy to prevent LBW. This study recommended continuation research about maternal comorbidities among $<20$ years old pregnant women to analyze the factor of LBW based on comorbidities.

\section{ACKNOWLEDGMENTS}

We would like to thank the support from the Health Science Institute of Strada Indonesia, Blitar District Health Office, all primary health care in Blitar District, and the midwives for facilitating the research.

\section{REFERENCES}

Al-Ramahi, M., \& Saleh, S. (2006). Outcome of adolescent pregnancy at a university hospital in Jordan. Archives of Gynecology and Obstetrics, 273(4), 207-210.

Denantika, O., Serudji, J., \& Revilla, G. (2015). Hubungan Status Gravida dan Usia Ibu terhadap Kejadian Preeklampsia di RSUP Dr. M. Djamil Padang Tahun 2012-2013. Jurnal Kesehatan Andalas, 4(1).

Kosim. (2012). Buku Ajar Neonatologi. Jakarta: Badan Penerbit IDAI.

Kovavisarach, E., Chairaj, S., Tosang, K., Asavapiriyanont, S., \& Chotigeat, U. (2010). Outcome of teenage pregnancy in Rajavithi Hospital. Journal of the Medical Association of Thailand, 93(1), $1-8$.

Kurniawati, L. (2010). Hubungan Pre Eklampsia dengan Kelahiran Berat Bayi Lahir Rendah (BBLR) di RSUD Sragen. Universitas Negeri Sebelas Maret.

Manuaba. (2012). Ilmu Kebidanan, Penyakit Kandungan dan Keluarga Berencana Untuk Pendidikan Bidan. Jakarta: EGC.

Ministry of Health of Republic of Indonesia. (2010). 2010 Basic Health Data (Riset Kesehatan Dasar 2010). Jakarta.

Ministry of Health of Republic of Indonesia. The Ministrial Regulation No. 97 Year 2014 (Peraturan Menteri Kesehatan Republik Indonesia Nomor 97 Tahun 2014) (2015). The Republic of Indonesia. 
Ministry of Health of Republic of Indonesia. (2018a). Main Report of 2018 Basic Health Data in East Java Province (Hasil Utama Riskesdas 2018 Provinsi Jawa Timur). Jakarta.

Ministry of Health of Republic of Indonesia. (2018b). The Main Report of Basic Health Data 2018. (Hasil Utama Laporan Riskesdas 2018). Jakarta.

Mubasyiroh, R., Tejayanti, T., \& Senewe, F. (2016). Hubungan Kematangan Reproduksi dan Usia saat Melahirkan dengan Kejadian Bayi Berat Lahir Rendah (BBLR) di Indonesia Tahun 2010. Jurnal Kesehatan Reproduksi, 7(2), 109-118.

Nurhayati, Wigunantiningsih, A., \& Hastutik. (2018). Hubungan Keteraturan Antenatal Care dengan Berat Badan Bayi Baru Lahir di Bidan Praktik Swasta Puspita Hati Jumapolo Karanganyar. Jurnal Maternal, 2(4), 250-254.

Nurmalasari, Y., \& Mustofa, F. I. (2014). Hubungan Keteraturan Pemeriksaan Kehamilan pada Ibu Primigravida dengan Angka Kejadian Bayi Berat Lahir Rendah di Puskesmas Kecamatan Pademangan Jakarta Utara Tahun 2010-2014. Jurnal Medika Malahayati, 1(4), 175-184.

Prawirohardjo, S. (2010). Anemia dalam Kehamilan (4th ed.). Jakarta: Yayasan Bina Pustaka.

Prianita, A. W., \& Cahyanti, R. D. (2011). Pengaruh Faktor Usia Ibu terhadap Keluaran Maternal dan Perinatal pada Persalinan Primigravida di Rs Dr. Kariadi Semarang Periode Tahun 2010. Universitas Diponegoro.

Putri, N. K. S. E. (2014). Hubungan Keteraturan Antenatal Care dengan Berat Badan Lahir Bayi di Rumah Bersalin Sehta, Ngargoyoso, Karanganyar.

Rahmi, Arsyad, D. S., \& Rismayanti. (2014). Faktor-Faktor yang Berhubungan dengan Kejadian Bayi Berat Badan Lahir Rendah Di RSIA Pertiwi Makassar. Jurnal Epidemiologi FKM Universitas Hasanudin.

Rizkah, Z., \& Mahmudiono, T. (2017). Hubungan Antara Umur, Gravida , Dan Status Bekerja Terhadap Resiko Kurang Energi Kronis ( KEK ) Dan Anemia Pada Ibu Hamil Relationship Between Age, Gravida, And Working Status Against Chronic Energy Deficiency And Anemia In Pregnant Women. Amerta Nutrition, 1(2), 72-79. https://doi.org/10.20473/amnt.v1.i2.2017.72-79

Sholiha, H., \& Sumarmi, S. (2015). Analisis Risiko Kejadian Berat Bayi Lahir Rendah (BBLR) pada Primigravida. Media Gizi Indonesia, 10(1), 57-63.

Wati, L. K. (2013). Hubungan antara preeklampsi/ eklampsi dengan kejadian berat lahir rendah (BBLR) di RSUD Dokter Soedarso Pontianak tahun 2012. Jurnal Mahasiswa PSPD FK Universitas Tanjungpura, 3(1). 